\title{
Study on the Reform of English and American Literature Teaching under the Background of Internet
}

\author{
Li Kuang ${ }^{1, a}$ \\ ${ }^{1}$ Jiangxi Institute of Economic Administrators, Nanchang, Jiangxi, 330088
}

Keywords: Network, English and American Literature Teaching, Reform

\begin{abstract}
An important traditional course in English is English and American literature. But now the rapid development of the network makes the English literature is facing all kinds of difficulties and shortcomings, people of today's era are the pursuit of pragmatism, leading to the current liberal arts class in the increasingly marginalized, so the reform of Anglo-American literature curriculum can not be delayed The In the Internet age, the network plays an important role in the field of literary teaching, and in the network we can find it more than real life teachers in the more favorable place, so we should take full advantage of the network in the Anglo-American literature reform.
\end{abstract}

\section{Introduction}

Anglo - American literature class plays an important role in the education of English majors in China. He plays a key role in cultivating Chinese students' ability to read, appreciate and understand literature. At present, our students can not fully adapt to the Anglo-American literature teaching, because contemporary students pursue pragmatism, that the British and American literature is useless, so they will have a sense of disgust for English and American literature. For them, we can not feel the charm of Anglo-American literature, we should change the Anglo-American literature teaching methods to make students interested in Anglo-American literature, enhance their understanding of Anglo-American literature, so that they can learn the culture of other countries, for the promotion of personal cultural level has a pivotal role.

\section{The Present Situation of English and American Literature Teaching under the Background of Internet}

With the rapid development of the network, people get the new knowledge of the way has gradually become more, access to information has become more simple and people only need to enter some keywords in their mobile phone, you can find what you want. It is also so that people in today's era more practical, for those who feel useful, will go to further understanding, but people in the pursuit of practicality at the same time will fall a lot of things, so we should be a Kind of normal mentality to learn. In the case of British and American literature is faced with all kinds of difficulties and shortcomings, some colleges and universities in order to adapt to external development, too much to emphasize the practicality. At present, most colleges and universities lack the preparation of British and American literature classes, but rather to increase the number of other more practical English applied courses and it is through such courses, so that the students are in the pursuit of practicality on the road. To this end, the current British and American literature class is less and less, but in the curriculum at the same time it has increased its content, the teacher that the traditional single mathematical methods have been unable to adapt to contemporary students of English learning, and now Students are not aware of the importance and role of literary courses, and their current learning does not have a clear goal, which is the contemporary students of Anglo-American teaching is not interested in the reason, leading to the current Anglo-American literature class in the increasingly marginal situation The

With the foreign language education scholars on the status quo of Anglo-American literature teaching attention, many colleges and universities also reform the Anglo-American literature teaching, this reform also allows more and more people to understand the importance of 
Anglo-American literature teaching. But the current Anglo-American literature still has a lot of shortcomings, we should continue to find solutions from the Anglo-American literature, and from the student interest and other aspects of the start, combined with contemporary features, the network into the Anglo-American literature reform, Is a major reform of English and American literature teaching, and in accordance with the characteristics of today's era, the introduction of the network into the Anglo-American literature teaching is also one of the most effective way to reform.

\section{The Network Era under the Background of English and American Literature Teaching Strategies}

In the past, the teaching of English and American literature was in the era of backward teaching conditions, and the teachers 'strength was weak. So at that time, the teaching of English and American literature in our country was mainly the traditional teaching mode of teachers' listening to students. This model seriously bound the students Of the self-thinking ability, and through the teaching reform in recent years, this teacher-based teaching model can not be very effective in imparting knowledge, just let the teacher can be more dominant, this teacher-centered The teaching model is conducive to the supervision of the students to the students, through the system to impart knowledge so that everyone can learn the same self-knowledge, but this type of teaching students are not able to digest those knowledge, and this serious So that we can add the network to the Anglo-American literature teaching mode, through the network to solve this dry teaching methods, the network of a large number of resources on the Anglo-American literature teaching, the United States and the United States, So that students can learn more knowledge, teachers through interactive teaching model to enhance students' ability of independent innovation, so that the classroom is not limited to the classroom, by promoting students to learn to stimulate students to learn interest, The development of their associative thinking, in this interactive teaching mode, the students can be free and teachers to explore the issue, which is the original teaching model can not reach,

Many students who study English do not really recognize the meaning of literature. They simply think that literature is a very culturally important culture, so in general they have a look of respect for literature, which leads to Many students did not learn English and American literature, followed by the British and American literature in an awkward position. In fact, for English students, Anglo-American literature can improve their English performance, learning Anglo-American literature can make students' self-cultivation has been greatly improved, and in the study of literary knowledge can be a better understanding of the literature, From the literature to learn the main content of Anglo-American literature, found in the Anglo-American literature in the interesting place, which is to improve the enthusiasm of the students have a great help. In such a network era, anytime, anywhere can learn knowledge, so students learn knowledge is on their own initiative, but now the network also carries a lot of harm, if the students can not control the time of the arrangements, then it will So we should let the students can appreciate the fun of Anglo-American literature, found that literature can also read through audio-visual materials, through new learning methods to understand the Anglo-American literature, so as to improve the enthusiasm of the students, so that Students can actively learn literary knowledge.

The traditional English and American literature textbooks are basically the same, not the same is the teachers of their own lesson preparation materials, teachers in the preparation of materials when the preparation is very hard, those materials require teachers to put together in advance, but some teachers will not produce, Or that time is too expensive, so the teachers will ask those who have prepared the lesson preparation materials for help, but the situation is not the same for each class, so this lesson material can not play its role, but also a waste The teachers of their efforts, this will seriously affect the teaching efficiency, for teachers and students is an urgent need to solve the problem. The network used in the lesson is able to solve this problem, because the network has a wealth of resources for teachers to choose the lesson preparation materials, not only can save a lot of time, you can also find resources directly on the network, and then through the link display In the courseware, and the link can also be sent to the students, so that students can use the time after class 
to consolidate the time to learn the knowledge, not only can save time to take notes in class, but also in the review when there is a clear Of the outline, which not only increased the time in the classroom, but also allow students to learn more easily, so that the interaction time in the classroom will increase, so that students learn efficiency greatly improved.

Teaching materials in the field of literature plays a key role, because we are in the classroom to learn the knowledge is the need for teaching materials, so in the Anglo-American literature teaching materials is essential, the teachers have to spend time in the lesson preparation materials , But the use of the network, we can quickly find the materials you want, so the teachers in the lesson will be a lot easier, teachers can also try to work with students to produce materials, and even encourage students to Complete the preparation materials, so that not only can mobilize the enthusiasm of students to learn literary knowledge, but also through the preparation of lesson materials to promote the exchange of teachers and students, so that students can more calmly learn English and American literature knowledge. Students are more familiar with the students than the students, so the students prepare the lesson materials may be more attractive to students, can also be integrated into the students, through mutual exchanges to enhance the status of teachers. The exchange of teachers and students can improve students 'enthusiasm for learning and promote students' interest in English and American literature. For teachers and students in English and American literature teaching, teachers need to find the interest and motivation of students to get rid of the boring So that communication and communication between teachers and students is very important, and this has played an important role in the reform of English and American literature teaching.

\section{Conclusion}

The network plays an irreplaceable position in the teaching reform of Anglo-American literature. The network brings infinite creativity to English and American literature teaching. Therefore, teachers should have the basic knowledge of the network. Although there are many problems at the beginning, teachers also Do not have to worry, you should find a solution from the problem, which can be more skilled to solve the problem and reduce the emergence of the problem, we can gradually in the context of the network to find a new British and American literature teaching model, make full use of the vast network of resources So that students can learn English and American literature more effectively.

\section{References}

[1] Lu Rui. Challenges and Countermeasures of Undergraduate Foreign Literature Teaching under the Background of Network Times [J]. Journal of Guizhou Normal University, 2014, (06): 130-133

[2] Wu Ling. On the network era under the British and American literature teaching reform [J]. Journal of Jiamusi Education Institute, 2012, (03): 276 + 279 